\title{
Metals(loids) targeting fish eyes and brain in a contaminated estuary - Uncovering neurosensory (un)susceptibility through bioaccumulation, antioxidant and morphometric profiles
}

\author{
Ricardo Pereira $^{\mathrm{a}}$, Eduarda Leite ${ }^{\mathrm{a}}$, Joana Raimundo ${ }^{\mathrm{b}}$, Sofia Guilherme ${ }^{\mathrm{a}}$, Sónia Puga ${ }^{\mathrm{c}, \mathrm{d}}$, \\ Filipa Pinto-Ribeiro ${ }^{c, d}$, Maria Ana Santos ${ }^{\mathrm{a}}$, João Canário ${ }^{\mathrm{e}}$, Armando Almeida ${ }^{\mathrm{c}, \mathrm{d}}$, Mário Pacheco ${ }^{\mathrm{a}}$, \\ Patrícia Pereira ${ }^{\mathrm{a}, *}$ \\ a Department of Biology and CESAM, University of Aveiro, 3810-193 Aveiro, Portugal \\ b IPMA - Portuguese Institute of Sea and Atmosphere, Rua Alfredo Magalhães Ramalho, 6, 1495-006 Lisboa, Portugal \\ ${ }^{\mathrm{c}}$ Life and Health Sciences Research Institute (ICVS), School of Medicine (EM), Campus of Gualtar, University of Minho, 4750-057 Braga, Portugal \\ d ICVS/3B's - PT Government Associate Laboratory, Braga/Guimarães, Portugal \\ e Centro de Química Estrutural, Instituto Superior Técnico, Universidade de Lisboa, Av. Rovisco Pais, 1049-001 Lisboa, Portugal
}

\section{A R T I C L E I N F O}

\section{Keywords:}

Neurosensory toxicity

Antioxidant defenses

Brain stereology

Wild fish

Estuaries

\begin{abstract}
A B S T R A C T
This study examined the susceptibility of fish (Liza aurata) eyes and brain to metals(loids) contamination under realistic exposure conditions. A multidimensional approach was applied to fish caught at a chronically contaminated site (BAR) and at a reference site of the Tagus estuary (Portugal), which comprised metals(loids) accumulation in eyes and brain together with a battery of enzymatic and non-enzymatic antioxidants, as well as brain morphometry (i.e. cell density). Trace element levels in the blood, gills, liver and kidney allowed interpretations on their preferential pathway(s) to the eyes and brain. Metals(loids) accumulation pointed out the elevated vulnerability of the fish eyes at BAR, probably related with the direct waterborne uptake. Pb uptake in L. aurata eyes could be associated both with water and indirect pathways. At the most contaminated site, metals (loids) were on the basis of pro-oxidant conditions in the ocular tissues, while no indication of toxicity was recorded in the brain. Overall, the results disclosed a differential bioaccumulation among fish organs, suggesting that, in the L. aurata population studied, metal organotropism underlie the lower susceptibility of the brain comparing to the eyes. However, mechanisms remain little understood and further work is needed.
\end{abstract}

\section{Introduction}

Estuaries are among the most productive natural habitats of the world. Simultaneously, these ecosystems have been facing several anthropogenic pressures in the last decades, with emphasis on chemical pollution, particularly by trace elements (e.g. Zwolsman et al., 1996; Liu et al., 2017). In fact, the impact of trace elements in estuarine organisms has been largely reported (e.g. Guilherme et al., 2009; Pereira et al., 2010; Pereira et al., 2015; Marques et al., 2016; Graves et al., 2017; Piló et al., 2017), mainly because they are virtually non-degradable and tend to bioconcentrate, thus producing long lasting effects even after their major sources had been removed. While some elements like $\mathrm{Cu}, \mathrm{Zn}$ and $\mathrm{Fe}$ have a key role in metabolic and signaling functions in aquatic organisms, others such as $\mathrm{As}, \mathrm{Pb}, \mathrm{Cd}$ and $\mathrm{Hg}$ are highly toxic. Moreover, most of the elements with essential biological roles could be toxic above a threshold accumulation level, varying with a multitude of factors such as species and tissue.

Under chronic contamination, aquatic organisms are able to develop tolerance strategies towards metals. This is particularly well described for bivalves that, by altering metals toxicokinetics (regarded as a set of processes including uptake, distribution, sequestration and elimination) are able to reduce the harmfulness of these contaminants, as discussed recently in Marques et al. (in press). So far, these tolerance/adaptive mechanisms have been poorly reported in fish. There is the case of the brown trout (Salmo trutta) inhabiting a heavily contaminated freshwater system that accumulated extremely high levels of $\mathrm{Zn}, \mathrm{Cu}$ and $\mathrm{Fe}$ in the gills, liver and kidney, but a different pattern was found in the gut, suggesting that fish were probably limiting metals absorption at the gastrointestinal level (Webster et al., 2013). Other examples of fish populations adapted to metal contamination were reported elsewhere

\footnotetext{
* Corresponding author.

E-mail address: pkpereira@ua.pt (P. Pereira).
} 
mainly based on liver and gills analysis of freshwater species (Levesque et al., 2003; Pierron et al., 2009). Tolerance mechanisms in fish include several phenotypical expressions, such as changes in metal uptake and/ or elimination rates (Mulvey and Diamon, 1991). Contrastingly, no study had ever addressed fish sensory structures (as the eyes) or the brain in this context, preventing clarification on the association between metal toxicokinetics and the vulnerability of these organs under heavily contaminated scenarios. Disclosing the association between metals toxicokinetics and the vulnerability of eyes and brain to metals is particularly important since both organs are potentially well protected by histophysiological barriers, namely the BRB (blood-retinal barrier) and BBB (blood-brain barrier), respectively.

Most studies on environmental health assessment selected fish liver, kidney and gills to evaluate the quality of coastal systems, also correlating cause-effect relationships with animals' health (e.g. Mieiro et al., 2009; Pereira et al., 2010; Guilherme et al., 2012). Only the most recent studies on environmental health assessment have considered fish neurosensory structures (NSS), such as the eyes, revealing that they can faithfully reflect estuarine contamination by metals (Pereira et al., 2014 , 2015). In fact, the eye has a wide surface area that is continuously in contact with the external medium. Thus, this neurosensory organ can be a relevant uptake route for metals. The eye lens, in particular, have a unique morphology and stability during the life of an organism, potentially offering a historical record of $\mathrm{Hg}$ exposures affecting fish throughout their lifetime (Korbas et al., 2008). Identically, only a couple of studies have used the brain to evaluate fish health status upon realistic exposure to trace elements, specifically to $\mathrm{Hg}$ (Mieiro et al., 2010, 2011; Pereira et al., 2015; Graves et al., 2017; Puga et al., 2018). Those studies evidenced that $\mathrm{Hg}$ targets the fish brain under field exposures and that accumulation levels could vary spatially and seasonally in close association with environmental availability. Mieiro et al. work (2011) was a step forward towards covering accumulation levels of $\mathrm{Hg}$ plus oxidative stress related effects in the brain. Those studies were exclusively focused on $\mathrm{Hg}$, while the accumulation of other potentially neurotoxic metals (particularly $\mathrm{Pb}$ ) in fish remained unexplored, so far. In the light of the extensive knowledge on metals neurotoxicity in mammals, the lack of information for fish is intriguing and needs to be mitigated. Moreover, to our knowledge, no study has ever put together fish eyes and brain to explore the toxic effects of metals in fish, which is a timely approach since these organs are closely linked in terms of fish physiology and behavior.

The enhancement of reactive oxygen species (ROS) generation and oxidative stress is one of the pivotal events related with the neurotoxicity of several metals ( $\mathrm{Mn}, \mathrm{Fe}, \mathrm{Pb}$ and $\mathrm{Hg}$ ) in mammals (Farina et al., 2011; Farina et al., 2013). This is partially related with the high affinity of those elements to thiol groups of proteins and non-protein molecules, namely glutathione (GSH). In particular, the formation of extractable complexes of $\mathrm{Hg}$ with GSH can lead to a decrease of GSH levels and then to ROS accumulation (Shanker and Aschner, 2003). Additionally, trace elements can induce oxidative stress due to its direct interaction with nucleophilic protein groups (Farina et al., 2013). Contrastingly, the mechanisms of metal toxicity in fish eyes and brain remains elusive, even if oxidative stress related parameters have been providing valuable insights on the vulnerability of fish brain to $\mathrm{Hg}$ upon laboratory exposures (Berntssen et al., 2003; Cardoso et al., 2017) and field studies (Mieiro et al., 2010, 2011; Graves et al., 2017). Other metals have also been demonstrated as highly neurotoxic to fish, such as $\mathrm{Pb}$ (Kim et al., 2017) or Cd (Beauvais et al., 2001). However, more studies are needed in order to unveil the mechanisms of metals' neurotoxicity in fish and effects at the neurosensorial level, specifically to disclose the interplay between bioaccumulation and the antioxidant system in the brain and eyes.

In order to unveil the neurotoxic effects of metals, rodent brains have been scrutinized using stereological methods, comprising an evaluation of cell numbers and volumes, which revealed adverse effects in the hippocampus and cerebellum (Larsen and Brændgaard, 1995;
Sørensen et al., 2000; Falluel-Morel et al., 2007; Sokolowski et al., 2013; Obiorah et al., 2015). This methodology allows clarification about the localized effects of metals in the nervous system of rodents. Unfortunately, this is a time-consuming method, which has mostly been used for toxicology purposes in mammals, allowing inferring about effects on humans. To the best of our knowledge, there are only three studies that employed stereological methods to evaluate the effects of trace elements (and only for $\mathrm{Hg}$ ) in fish, and these were performed by our research group (Pereira et al., 2016; Puga et al., 2016, 2018).

The present study discloses, for the first time, the effects of metals (and metalloids) accumulation in the eyes and brain of the native golden grey mullet (Liza aurata) under realistic exposure conditions to a metal contaminated environment (Barreiro in the Tagus estuary, Portugal). For that purpose, a battery of enzymatic and non-enzymatic antioxidants (both in eyes and brain) was considered together with metal accumulation levels, as well as a brain morphometric analysis (cell density). Moreover, considerations were made on how trace elements possibly reached the fish eyes and brain based on accumulation levels in a wider set of tissues, namely blood, gills, liver and kidney.

\section{Material and methods}

\subsection{Study area}

The current study was carried out in the Tagus estuary (Fig. 1), located in the Lisbon metropolitan area, which is the most populated area of Portugal (2.7 million people). This estuary, one of the largest in Europe $\left(320 \mathrm{~km}^{2}\right.$ of area), has an extremely high socio-economic importance, since it supports numerous industries and a high population density. Tagus estuary has a historic and intensive anthropogenic pressure, due to urban effluents from about 3 million inhabitants, together with contamination resultant from diverse chemical, petrochemical, metallurgic, shipbuilding, cement manufacture industries and agriculture fertilizers/pesticides (Duarte et al., 2008). These pressures led to a high accumulation of trace elements in sediments and organisms, particularly in the Barreiro area (Canário et al., 2005;

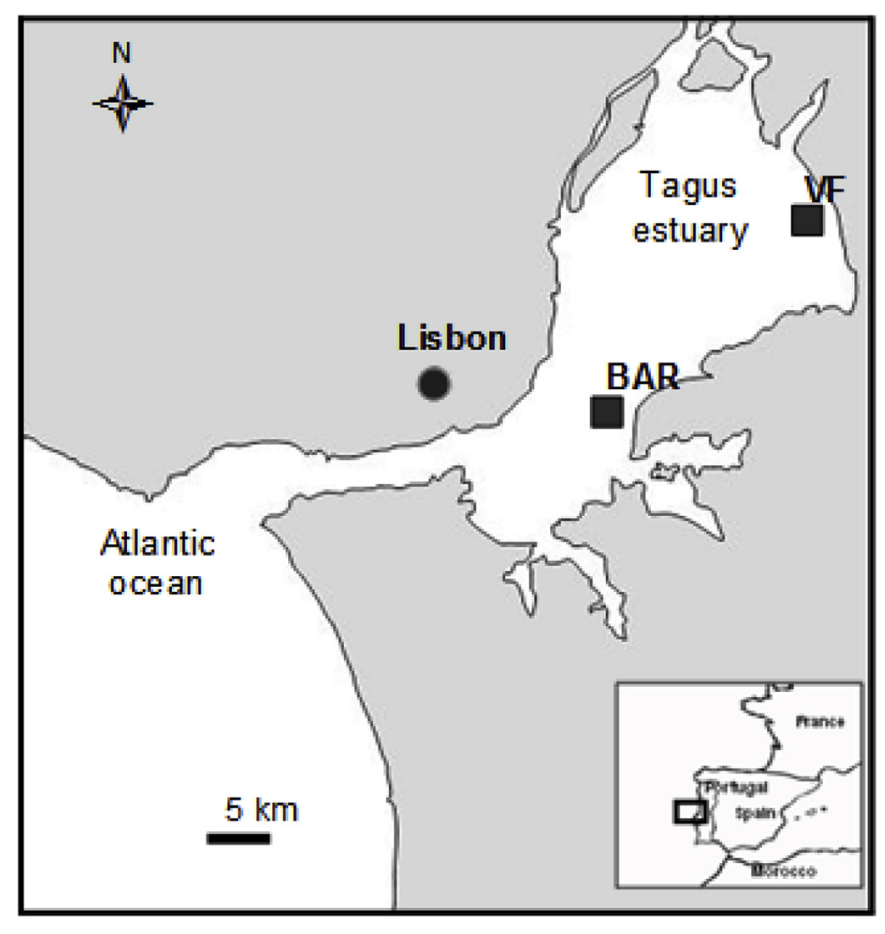

Fig. 1. Location of the sampling sites (BAR and VF; $\mathbf{\square})$ at the Tagus estuary (Portugal): Vale Frades (VF) $\left(38^{\circ} 45.186^{\prime} \mathrm{N}, 8^{\circ} 58.789^{\prime} \mathrm{W}\right)$; Barreiro (BAR) $\left(38^{\circ}\right.$ $\left.40.272^{\prime} \mathrm{N}, 9^{\circ} 5.207^{\prime} \mathrm{W}\right)$. 
França et al., 2005; Neto et al., 2011; Marques et al., 2016; Piló et al., 2017; Cesário et al., 2017). Levels of organic contaminants (PCBs, PAHs, DDTs) at BAR were reported to be low (IPIMAR, 2004). The Tagus estuary also comprises an important Natural Reserve with low anthropogenic impact, which is located in the northern part of the estuary in its southern margin.

\subsection{Sampling}

In winter (December 2011), a survey was carried out at the Tagus estuary during low-tide conditions. Two sampling sites were selected, taking into account previous studies on environmental quality (e.g. Canário et al., 2005; Vale et al., 2008) (Fig. 1), namely: Barreiro (BAR) in the most contaminated area (impacted mainly by trace elements) and Vale Frades (VF) located in the protected area of the Tagus Natural Reserve and thus, selected as the reference site.

At each sampling site, juvenile specimens of golden grey mullet ( $L$. aurata) were collected using a traditional beach-seine net and divided by the several components of the study, as following: (i) $n=5-10$ for metal determinations in gills, blood, liver, kidney, eyes and brain; (ii) $\mathrm{n}=8$ for antioxidants in the eyes and brain; (iii) $\mathrm{n}=5$ for brain stereology. Fish biometrical parameters, such as weight and total length ranged from 140 to $210 \mathrm{~g}$ and $25-35 \mathrm{~cm}$, respectively. Immediately after catching, fish were anesthetized, sacrificed and then, blood, gills, liver, kidney, eyes and brain were collected. Eyes and gills were carefully washed with distilled water. Samples for metal determinations were frozen at $-20^{\circ} \mathrm{C}$, while eyes (whole eyes, including lens, humors, sclera, retina, cornea, etc.) and brain samples for oxidative stress related endpoints were snap-frozen and preserved at $-80^{\circ} \mathrm{C}$. Brain samples for stereology were immersed and stored in paraformaldehyde $(4 \%)$.

Sub-surface water (at $0.2 \mathrm{~m}$ depth) was sampled in triplicates to polypropylene bottles for the determination of $\mathrm{Cu}, \mathrm{Pb}, \mathrm{Cd}, \mathrm{Hg}$ and $\mathrm{MeHg}$ in the dissolved fraction of water column. At the same depth, temperature, salinity, turbidity, $\mathrm{pH}$ and dissolved oxygen were measured in situ in triplicates with an YSI $650 \mathrm{~m}$. Surface sediments (approximately $2 \mathrm{~cm}$ depth) were also collected in the two sites with a Van Veen grab for metal determinations.

\subsection{Metals(loids) quantification in the water}

Copper, $\mathrm{Pb}$ and $\mathrm{Cd}$ in the collected waters (triplicate samples) were measured using diffusive gradients of thin films (DGT). All DGT holders, Chelex-100 resins and diffusive gels were purchased from DGT Research (Lancaster, UK). The DGT devices were deployed in 2-L polypropylene bottles with unfiltered sampled water and stirred at constant temperature for $48 \mathrm{~h}$. After retrieving the devices, resins were eluted by immersion in $5 \mathrm{~mL}$ of $1 \mathrm{M} \mathrm{HNO}_{3}$ (prepared from suprapure nitric acid) for a minimum of $24 \mathrm{~h}$. Eluates were analysed directly by a quadropole inductively coupled plasma mass spectrometer (ICP-MS) (Thermo Elemental, X-Series). All eluates were analysed with reagents blanks and an international standard of river water (SLRS-4) used to control eventual contaminations during the analytical procedure and the procedure accuracy, respectively. Water concentrations of $\mathrm{Cu}, \mathrm{Pb}$ and Cd were calculated according to Zhang and Davison (1999).

Total dissolved $\mathrm{Hg}$ was determined following the U.S.EPA method 1631 (U.S.EPA, 2002). Briefly, water samples were preserved by the addition of $0.5 \% \mathrm{BrCl}$ until analyses (less than one week after collection). The samples were then analysed through cold-vapour atomic fluorescence spectrometry (CV-AFS) with a PSA model Merlin 10.023 equipped with a detector PSA model 10.003 using $\mathrm{SnCl}_{2}$ reduction. BCR-579 reference material was used to control the accuracy of the procedure.

$\mathrm{MeHg}$ in water samples was determined following U.S.EPA method 1630 (U.S.EPA, 2001) by distillation of $50 \mathrm{~mL}$ sub-samples, after addition of $1 \% \mathrm{C}_{5} \mathrm{H}_{9} \mathrm{NS}_{2} \cdot \mathrm{NH}_{3}$ as a complexing agent. Mercury was ethylated with $\mathrm{NaB}\left(\mathrm{C}_{2} \mathrm{H}_{5}\right)_{4}$, purged with argon, collected on TenaxTM traps, separated with a GC, thermally desorbed to $\mathrm{Hg}(0)$ for detection of MeHg with a Brooks Rand Model III CV-AFS. All batches of samples analysed for $\mathrm{MeHg}$ included at least one method replicate, and at least three analytical replicates of certified reference material (SQC-1238) (Sigma-Aldrich RTC).

\subsection{Metals(loids) quantification in the sediment}

Sediment samples $(100 \mathrm{mg})$ were mineralized completely with $\mathrm{HF}$ (40\%) and Aqua Regia (HCl-36\%: $\mathrm{HNO}_{3}-60 \% ; 3: 1$ ) in closed Teflon bombs $\left(100{ }^{\circ} \mathrm{C}\right.$ for $1 \mathrm{~h}$ ), evaporated to near dryness (DigiPrep HotBlock - SCP Science), redissolved with $1 \mathrm{~mL}$ of doubled-distilled $\mathrm{HNO}_{3}$ and $5 \mathrm{~mL}$ of ultra-pure water, heated for $20 \mathrm{~min}$ at $75^{\circ} \mathrm{C}$, heated again for $20 \mathrm{~min}$ at $90^{\circ} \mathrm{C}$ after ultra-pure water addition $(25 \mathrm{~mL})$, and diluted to $50 \mathrm{~mL}$ with ultra-pure water. The concentrations of $\mathrm{Zn}, \mathrm{As}, \mathrm{Cu}, \mathrm{Pb}$ and $\mathrm{Cd}$ were determined by ICP-MS. Sediment samples were analysed for total $\mathrm{Hg}$ by atomic absorption spectrometry (AAS) with thermal decomposition with gold amalgamation, using a mercury analyser (AMA) LECO 254 (Costley et al., 2000). Reagent blanks and international certified standards of sediments from the National Research Council of Canada (1646a; BCSS-1; MESS-3) were prepared in a similar way as samples to control the accuracy of the procedure. Levels of the analysed elements obtained in the reference materials were consistent within the ranges of certified values.

\subsection{Metals(loids) quantification in fish tissues}

At the laboratory, eyes and gills were washed again with gentle rubbing (to remove the remaining adherent particles). Blood, gills, liver, kidney, eyes and brain samples were lyophilised and homogenised. Then, approximately $50 \mathrm{mg}$ of freeze dried tissue was digested with a mixture of $\mathrm{HNO}_{3}$ (doubled distilled from 65\%) and $\mathrm{H}_{2} \mathrm{O}_{2}$ (suprapure, $30 \%$ ) at $60^{\circ} \mathrm{C}$ for $12 \mathrm{~h}$, at $100^{\circ} \mathrm{C}$ for $1 \mathrm{~h}$ and at $80^{\circ} \mathrm{C}$ for $1 \mathrm{~h}$ according to the method described in Pereira et al. (2010). Procedural blanks were prepared using the same analytical procedure and reagents. Concentrations of $\mathrm{Zn}, \mathrm{As}, \mathrm{Cu}, \mathrm{Pb}$ and $\mathrm{Cd}$ were determined by ICP-MS. Eye samples were analysed for total $\mathrm{Hg}$ as previously described for sediment. International certified standards (TORT-2, DORM-3 and DOLT-4) were used to control the accuracy of the analytical procedures.

\subsection{Enzymatic and non-enzymatic antioxidants}

Eye tissues (lens were discarded) were homogenised in a 1:5 ratio ( $1 \mathrm{~g}$ of tissue: $5 \mathrm{~mL}$ of buffer) of ice-cold phosphate buffer $(0.1 \mathrm{mM}$ and $\mathrm{pH}$ 7.4) using a Potter-Elvehjem glass-Teflon homogenizer. Then, the homogenate was centrifuged at $13,400 \mathrm{~g}$ for $25 \mathrm{~min}$, and the post $\mathrm{mi}$ tochondrial supernatant (PMS) was divided into aliquots to be used for antioxidants determinations. PMS aliquots were stored at $-80^{\circ} \mathrm{C}$ until analyses. The preparation of brain samples followed an identical procedure with the sole difference that less volume of phosphate buffer was used in the homogenization $(250 \mu \mathrm{L})$ due to the reduced sample amount. The following parameters were determined spectrophotometrically (Jasco V-503) in the PMS of eyes and brain at $25{ }^{\circ} \mathrm{C}$ :

- Catalase (CAT) activity was assayed by the method of Claiborne (1985) as described by Giri et al. (1996). For analysis, the assay mixture consisted of $1.95 \mathrm{~mL}$ phosphate buffer $(0.05 \mathrm{M}$; $\mathrm{pH}=7.0)$, $1 \mathrm{~mL}$ hydrogen peroxide $(0.019 \mathrm{M})$ and $50 \mu \mathrm{L}$ of sample in a final volume of $2 \mathrm{~mL}$. The change in absorbance was recorded spectrophotometrically at $240 \mathrm{~nm}$ for $1.5 \mathrm{~min}$ and CAT activity was calculated in terms of $\mu \mathrm{mol} \mathrm{H}_{2} \mathrm{O}_{2}$ consumed $/ \mathrm{min} / \mathrm{mg}$ protein $(\varepsilon=43.5$ $\mathrm{M}^{1} \mathrm{~cm}^{1}$ );

- Glutathione peroxidase (GPx) activity was assayed according to the method described by Mohandas et al. (1984). The assay mixture consisted of $0.720 \mathrm{~mL}$ phosphate buffer $(0.05 \mathrm{M} ; \mathrm{pH}=7.0)$, 
$0.050 \mathrm{~mL}$ EDTA $(1 \mathrm{mM}), 0.050 \mathrm{~mL}$ sodium azide $(1 \mathrm{mM}), 0.025 \mathrm{~mL}$ glutathione reductase $(1 \mathrm{U} / \mathrm{mL}), 0.050 \mathrm{~mL}$ reduced glutathione (GSH; $4 \mathrm{mM}), 0.050 \mathrm{~mL}$ NADPH $(0.8 \mathrm{mM}), 0.005 \mathrm{~mL} \mathrm{H}_{2} \mathrm{O}_{2}(0.5 \mathrm{mM})$ and $0.050 \mathrm{~mL}$ of sample in a total volume of $1 \mathrm{~mL}$. GPx activity was determined monitoring the oxidation of $\mathrm{NADPH}$ to $\mathrm{NADP}^{+}$, resulting in absorbance decrease at $340 \mathrm{~nm}$ for $3 \mathrm{~min}$. The enzyme activity was calculated as nmol $\mathrm{NADP}^{+}$oxidized $/ \mathrm{min} / \mathrm{mg}$ of protein $\left(\varepsilon=6.22 \times 10^{3} \mathrm{M}^{-1} \mathrm{~cm}^{-1}\right)$;

- Glutathione-S-transferase (GST) activity was determined using CDNB (1-chloro-2,4-dinitrobenzene) as substrate, according to the method of Habig et al. (1974). The assay was carried out with a $2.0 \mathrm{~mL}$ mixture of $1.89 \mathrm{~mL}$ phosphate buffer $(0.2 \mathrm{M}$; $\mathrm{pH}=7.9)$, $0.050 \mathrm{~mL}$ CDNB $(0.2 \mathrm{mM}), 0.050 \mathrm{~mL}$ GSH $(0.2 \mathrm{mM})$ and $0.010 \mathrm{~mL}$ of sample. The reaction was initiated by addition of $0.01 \mathrm{~mL}$ of sample, and the increase in absorbance was recorded spectrophotometrically at $340 \mathrm{~nm}$ for $3 \mathrm{~min}$. The enzyme activity was calculated as nmol CDNB conjugate formed/min/protein $\left(\varepsilon=9.6 \mathrm{mM}^{-1} \mathrm{~cm}^{-1}\right)$;

- Glutathione reductase (GR) activity was measured according to the method of Cribb et al. (1989). The reaction medium consisted of phosphate buffer $(0.05 \mathrm{M}$; $\mathrm{pH}=7.0), 0.5 \mathrm{mM}$ DTPA, $0.2 \mathrm{mM}$ NADPH and $1 \mathrm{mM}$ GSSG. A volume of $50 \mu \mathrm{L}$ of sample was added to $950 \mu \mathrm{L}$ of the reaction medium. Enzyme activity was spectrophotometrically measured by assessing NADPH disappearance at $340 \mathrm{~nm}$ for $3 \mathrm{~min}$ and expressed of NADPH oxidized/min/mg protein $\left(\varepsilon=6.22 \times 10^{3} \mathrm{M}^{-1} \mathrm{~cm}^{-1}\right)$;

- Superoxide dismutase (SOD) activity was assayed with RANSOD kit (Laboratories Ltd, UK). The method uses xanthine and xanthine oxidase to generate superoxide radicals, which react with 2-(4-iodophenyl)-3-(4-nitrophenol)-5-phenyltetrazolium chloride (INT) to form a red formazan dye. SOD activity is them measured by the degree of inhibition of this reaction. One unit of SOD is the amount that causes a $50 \%$ inhibition of the rate of reduction of INT, under the conditions of the assay. The procedure starts with the determination of calibration curve using standard solution. The standard solution was diluted and the percent inhibition was calculated. Found curve, the samples were measured at an absorbance at $505 \mathrm{~nm}$ for $3 \mathrm{~min}$. The samples showed an inhibition range between 30 and $60 \%$, and the eye analysis was performed in a 1:10 ratio (10 $\mu \mathrm{L}$ sample: $90 \mu \mathrm{L}$ buffer) while brain analysis was performed in a 1:20 ratio ( $10 \mu \mathrm{L}$ sample: $190 \mu \mathrm{L}$ buffer). Results were expressed as SOD units/mg protein.

- Total glutathione content (tGSH) was determined using deproteinated PMS adopting the enzymatic recycling method of using GR excess (Baker et al., 1990; Tietze, 1969), whereby the sulfhydryl group of GSH reacts with DTNB (Ellman's reagent) and produces a yellow 5-thio-2-nitrobenzoic acid (TNB). Formation of TNB was measured by spectrophotometry at $412 \mathrm{~nm}$ for $6 \mathrm{~min}$. The results are expressed as nmol TNB formed $/ \mathrm{min} / \mathrm{mg}$ protein $\left(\mathcal{E}=1.41 \times 10^{3} \mathrm{M}^{-1} \mathrm{~cm}^{-1}\right)$.

- Total protein content was determined according to the Biuret method (Gornall et al., 1949), using bovine serum albumin (E. Merck-Darmstad, Germany) as a standard. Absorbance was measured at $550 \mathrm{~nm}$.

\subsection{Brain stereology}

The processing of the brain tissue undergoing the stereological analysis was conducted as previously described (Pereira et al., 2016; Puga et al., 2016, 2018). Briefly, the brains were fixed in 4\% paraformaldehyde during $72 \mathrm{~h}$, and were embedded in glycolmethacrylate resin blocks (Technovit 7100, Heraeus Kulzer, Wehrheim, Germany). The brains were then serially sectioned in the coronal plan (thickness of $30 \mu \mathrm{m}$ ) and were stained using a solution of $20 \%$ Giemsa's azur eosin methylene blue (Merck, Darmstadt, Germany). Using anatomical landmarks and cytoarchitectural criteria, main brain regions were identified (lateral pallium, hypothalamus, optic tectum and cerebellum)
(Pereira et al., 2016; Puga et al., 2016, 2018).

The stereology workstation comprised the StereoInvestigator software (MicroBrightField, Williston, VT, USA) and a camera (DXC390; Sony, Tokyo, Japan) attached to a motorized microscope (Axioplan 2; Zeiss, Oberkochen, Germany) with Plan-Neofluar objectives: $2.5 \times$ (N.A. 0.075) for delineation of the regions of interest, and $100 \times$ oil (N.A. 1.30) for the cell counting.

To estimate the volume according to the Cavalieri's principle (Gundersen and Jensen, 1987; Gundersen et al., 1988), the brain was systematically sectioned (sections sampled were separated by an equal distance) and randomly sampled (the first sampled section was randomly selected). Thus, in every selected section for analysis (8th section throughout the brain), the brain regions of interest present in the section were outlined (final magnification of $25 \times$ ) and their cross-sectional area was obtained. The volume for each brain region was then calculated as previously described in Puga et al. (2018). Total number of cells (neurons plus glia) was estimated using the optical fractionator method, as previously detailed in Pereira et al. (2016) and Puga et al. (2018). The total cell numbers were then calculated from the numbers of counted cells and the corresponding sampling probability as described by West et al. (1991). Finally, the cell densities (Fig. 4) were calculated as the ratio of the total cell number (obtained by the optical fractionator method) and the Cavalieri-estimated volume of the individual brain regions (Höistad et al., 2013; Richards et al., 2013). Representative coronal sections through the $L$. aurata's brain, illustrating the locations of the brain regions analysed, as well as high magnification photomicrographs showing different cell types within each region, were recently published in Puga et al. (2018).

\subsection{Data analysis}

All variables (element concentrations, antioxidants and brain cell density) were evaluated for normality [absolute skew value $<2$ and kurtosis $<7$ as proposed by West et al. (1995)]. Since this criterion was well met by all variables, it was employed a Student's $t$-test (unpaired, two-tailed) using, when appropriate, the Welch's correction for unequal variances (tested using the F-test to compare variances). A $p$-value $<$ 0.05 was regarded as statistically significant. Statistical analyses were performed using GraphPad Prism version 7.01 for Windows (GraphPad Software, La Jolla, CA, USA).

\section{Results}

\subsection{Water and sediment characteristics}

Inter-site differences of water physical-chemical parameters were found for salinity, which was lower in VF than BAR, related with Tagus river inputs (Table 1). BAR differed also from VF in terms of turbidity (2 times higher at BAR). Higher levels of dissolved metals(loids) were consistently found at BAR, and this was particularly accentuated for $\mathrm{MeHg}$ (39 times), followed by total $\mathrm{Hg}$ and $\mathrm{Pb}$ (around 25 times) (Table 1). Accordingly, concentrations of $\mathrm{Zn}, \mathrm{As}, \mathrm{Cu}, \mathrm{Pb}, \mathrm{Cd}$ and tHg in surface sediments were considerably higher at BAR than VF (Table 2). Levels of $\mathrm{Pb}$ and $\mathrm{tHg}$ at BAR sediments exceeded almost 7 times those recorded at $\mathrm{VF}$, while As and $\mathrm{Cd}$ were 5 times higher at BAR when compared with VF. Inter-site differences for $\mathrm{Zn}$ and $\mathrm{Cu}$ were not so accentuated, but even though were about 4 and 3 times higher at BAR than $\mathrm{VF}$, respectively.

\subsection{Metals(loids) levels in fish tissues}

Zinc and $\mathrm{Cu}$ levels were significantly higher in the gills and eyes of BAR fish, while levels of $\mathrm{Cu}$ in the liver were significantly higher at VF (Fig. 2). Moreover, levels of As and tHg were significantly higher in the eyes of BAR fish in comparison with VF. A significant accumulation of $\mathrm{Pb}$ was recorded in all the analysed tissues (except brain) of BAR fish, 
Table 1

In situ physical-chemical parameters and metal levels $[\mathrm{Cu}, \mathrm{Pb}, \mathrm{Cd}$, total $\mathrm{Hg}$ $(\mathrm{tHg})$, methylmercury $(\mathrm{MeHg})]$ at mid-water collected in low-tide at Vale Frades (VF) and Barreiro (BAR) in the Tagus estuary (Portugal). Temp. - temperature; Sal. - salinity. Means and standard deviations are presented.

\begin{tabular}{llll}
\hline & & Site \\
\cline { 3 - 3 } & & VF & BAR \\
\hline Temp. & $\left({ }^{\circ} \mathrm{C}\right)$ & $14 \pm 0.03$ & $16 \pm 0.06$ \\
Sal. & & $11 \pm 0.1$ & $30 \pm 0.1$ \\
Turbidity & & $12.2 \pm 0.1$ & $29.9 \pm 0.7$ \\
$\mathrm{pH}$ & & $7.3 \pm 0.01$ & $6.8 \pm 0.01$ \\
$\mathrm{O}_{2}$ & $(\%)$ & $0.4 \pm 0.12$ & $6.9 \pm 0.03$ \\
$\mathrm{Cu}$ & $\left(\mu \mathrm{g} \mathrm{L}^{-1}\right)$ & $0.032 \pm 0.025$ & $0.90 \pm 0.19$ \\
$\mathrm{~Pb}$ & & $0.025 \pm 0.007$ & $0.08 \pm \pm 0.160$ \\
$\mathrm{Cd}$ & & 1.3 & $31.9 \pm 6.1$ \\
$\mathrm{tHg}$ & $\left.(\mathrm{ng} \mathrm{L})^{-1}\right)$ & 0.21 & $8.1 \pm 1.8$ \\
$\mathrm{MeHg}$ & & & \\
\hline
\end{tabular}

Table 2

Levels of $\mathrm{Zn}, \mathrm{As}, \mathrm{Cu}, \mathrm{Pb}$, Cd and total $\mathrm{Hg}$ (tHg) in surface sediments collected at Vale Frades (VF) and Barreiro (BAR) in the Tagus estuary (Portugal).

\begin{tabular}{|c|c|c|c|}
\hline & & \multicolumn{2}{|l|}{ Site } \\
\hline & & VF & BAR \\
\hline $\mathrm{Zn}$ & $\left(\mu g g^{-1}\right)$ & 221 & 806 \\
\hline As & & 21 & 101 \\
\hline $\mathrm{Cu}$ & & 37 & 111 \\
\hline $\mathrm{Pb}$ & & 61 & 417 \\
\hline $\mathrm{Cd}$ & & 0.42 & 2.0 \\
\hline $\mathrm{tHg}$ & & 0.50 & 3.3 \\
\hline
\end{tabular}

relatively to VF. Cd accumulation followed an identical spatial pattern for the gills, liver and eyes, i.e. higher levels at BAR. The brain was the only tissue that did not signalize spatial differences, namely the higher accumulation of metals(loids) at BAR in comparison with VF, as described for the other tissues.

Liver displayed the highest levels of all analysed elements (except $\mathrm{Pb}$ that peaked in the gills) regardless the sampling area (Fig. 2). Interestingly, the eyes presented levels of $\mathrm{Zn}$ and As of the same order of magnitude as the liver. tHg reached identical levels in liver and kidney that were higher than values recorded in the remaining tissues. In general, the lowest levels of metals(loids) were recorded in the blood ( $\mathrm{Cu}, \mathrm{As}$ ) and brain $(\mathrm{Zn}, \mathrm{Pb}, \mathrm{Cd}, \mathrm{MeHg}$ ), except for $\mathrm{tHg}$ accumulation that was minimum in the gills.

\subsection{Antioxidants in the eyes and brain}

Activities of SOD and GPx increased significantly in the eyes of fish from BAR in comparison to VF, as well as levels of total GSH (Fig. 3). Contrastingly, no inter-site differences were found for activities of CAT, GR and GST in the eyes. In general, no significant differences were found for antioxidant system related responses in the brain, with a sole exception for CAT activity that decreased significantly at BAR relatively to VF.

\subsection{Brain cell density}

The cell density (number of neurons plus glial cells per $\mathrm{mm}^{3}$ ) in the lateral pallium, hypothalamus, optic tectum and cerebellum did not differ significantly between BAR and VF (Fig. 4).
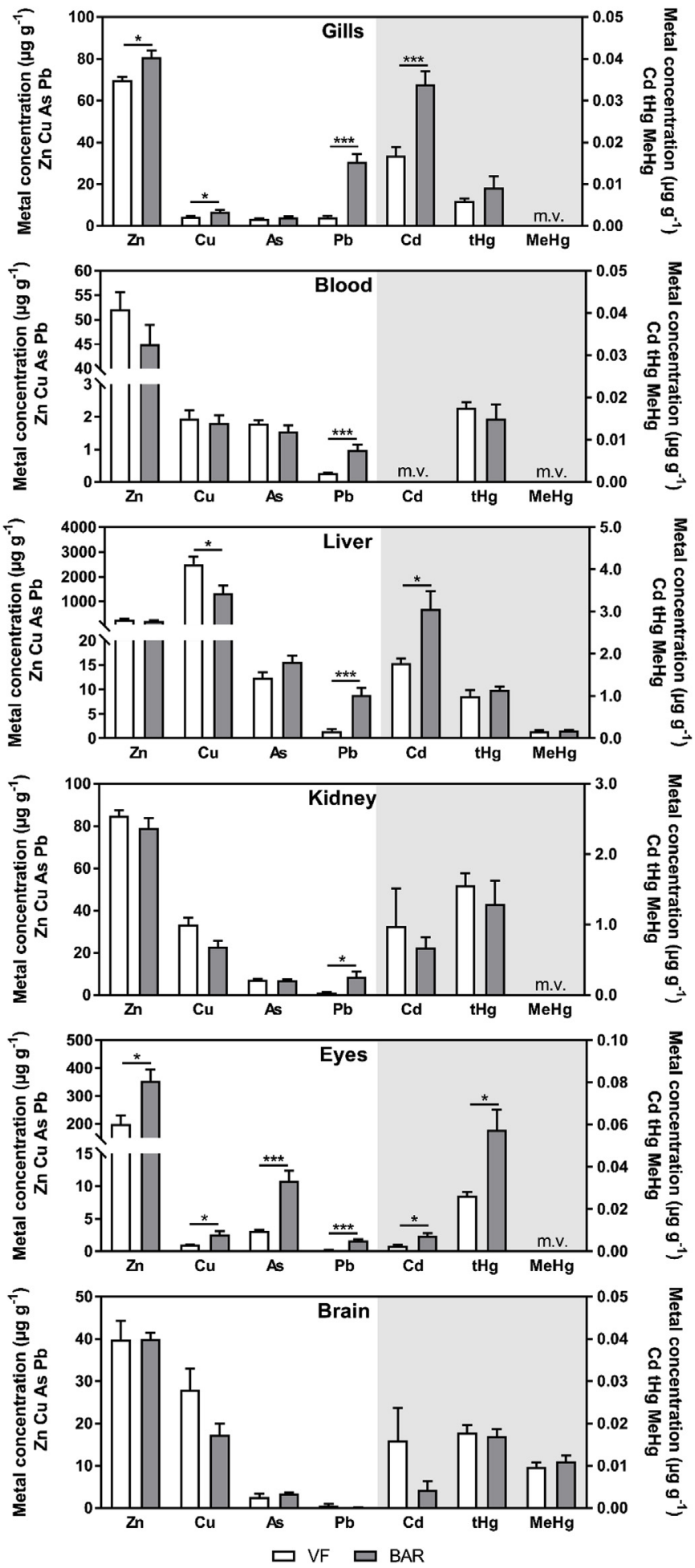

Fig. 2. Levels of $\mathrm{Zn}, \mathrm{Cu}$, As and $\mathrm{Pb}$ (left y-axis), as well as of $\mathrm{Cd}$, total $\mathrm{Hg}(\mathrm{tHg}$ ) and $\mathrm{MeHg}$ (right y-axis; grey background) in the gills, blood, liver, kidney, eyes and brain of Liza aurata from Vale Frades (VF) and Barreiro (BAR) at the Tagus estuary (Portugal). Data presented as mean \pm S.E.M; ${ }^{*} p<0.05$, $* * * p<0.001$. m. v. means "missed value".

\section{Discussion}

4.1. Metals(loids) bioaccumulation in the eyes and brain and insights on the underlying organotropism

The significantly higher accumulation of $\mathrm{Zn}, \mathrm{As}, \mathrm{Cu}, \mathrm{Pb}, \mathrm{Cd}$ and $\mathrm{Hg}$ 

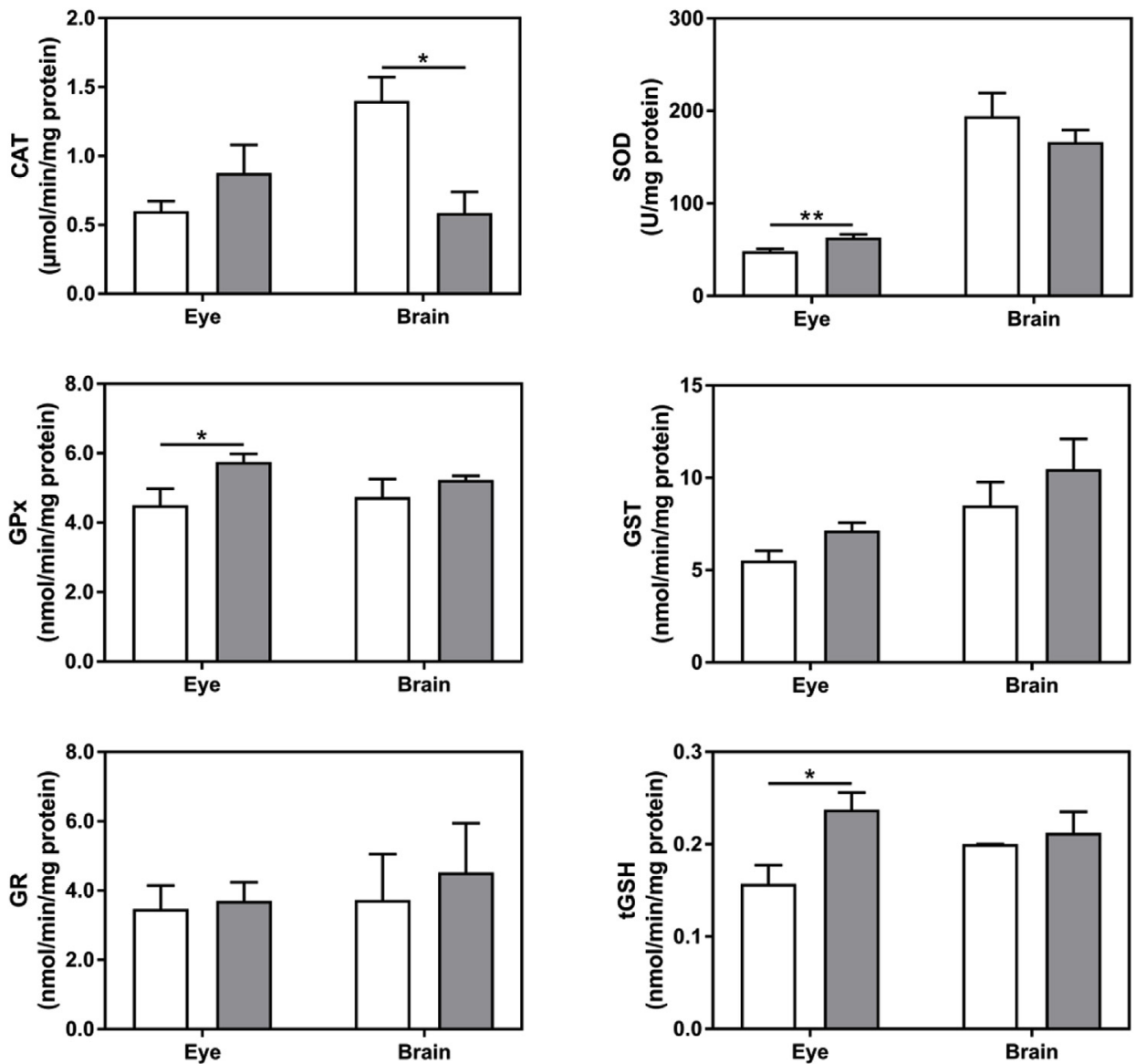

Fig. 3. Antioxidants in the eye and brain of Liza aurata caught at VF (Vale Frades) and BAR (Barreiro) in the Tagus estuary (Portugal), including activities of catalase (CAT), superoxide dismutase (SOD), glutathione peroxidase (GPx), glutathione-S-transferase (GST) and glutathione reductase (GR), as well as total glutathione content (tGSH). Data presented as mean \pm S.E.M; ${ }^{*} p<0.05$.

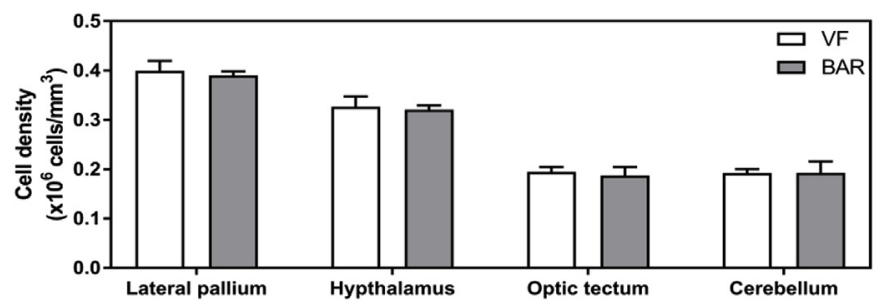

Fig. 4. Stereology-based estimates for cell density of individual brain regions of L. aurata aurata caught at VF (Vale Frades) and BAR (Barreiro) in the Tagus estuary (Portugal). Data presented as mean \pm S.E.M.

in the eyes of fish caught at BAR is in line with the elevated contamination by trace elements at this area of the Tagus estuary as pointed out by the current characterization of water and sediment matrices, which is in agreement with previous works (Canário et al., 2005; Vale et al., 2008; Piló et al., 2017). Levels of metals(loids) in the eyes of fish from BAR exceeded 2 to 3 times those recorded in specimens from $\mathrm{VF}$, while for $\mathrm{Pb}$ the difference was much higher (about 10 times). Elevated concentrations of $\mathrm{Pb}$ (and, to a lower extent, of $\mathrm{Cd}$ ) in the eyes of fish were already reported (Badsha and Goldspink, 1982). The current results are also in agreement with a previous study that described high levels of As in the eyes of a freshwater fish from a contaminated lake (Takatsu et al., 1999). Moreover, Korbas and coauthors (2008) investigated the uptake and accumulation of organic $\mathrm{Hg}$ in zebrafish larvae and found the highest levels in the lens epithelium of the eye, pointing out the propensity of fish eyes to accumulate organic $\mathrm{Hg}$ forms. The fish eyes are in permanent and direct contact to dissolved compounds, as well as to toxicants associated to suspended particles, suggesting the water as a main vehicle of trace elements. Besides that, it is probable that inorganic $\mathrm{Hg}$ (iHg) could reach the eyes by redistribution through the bloodstream as found out in a toxicokinetic study (Pereira et al., 2015), and hypothesized to explain the accumulation of $\mathrm{Hg}$ in fish eyes in a field research (Pereira et al., 2014). The same hypothesis had been raised for $\mathrm{MeHg}$ accumulation in zebrafish eyes by Korbas et al. (2013), who had also previously revealed substantial differences in tissue-specific accumulation patterns of $\mathrm{Hg}$ in zebrafish larvae exposed to four different $\mathrm{Hg}$ forms in water (Korbas et al., 2012). For MeHg species, the highest $\mathrm{Hg}$ concentrations were found in the eye lens epithelial cells, independent of the formulation ligand (chloride versus L-cysteine). For inorganic $\mathrm{Hg}$ species, in absence of $\mathrm{L}$-cysteine, the olfactory epithelium and kidney accumulated the highest amounts of $\mathrm{Hg}$. Although $\mathrm{Hg}$ in water at BAR is mainly present as inorganic forms, it co-occurs with $\mathrm{MeHg}$ hampering conclusions on the target tissue in association with $\mathrm{Hg}$ chemical forms. Those conclusions are also hindered by the co-occurrence of waterborne and dietary sources of $\mathrm{Hg}$ in field studies. The whole eye of $L$. aurata was analysed for metalloids (including lens, humors, sclera, retina, cornea, etc.), while it would be interesting to look further for trace elements distribution in different eye areas of L. aurata at contaminated ecosystems since it was previously demonstrated that the lens and retina have different affinities for $\mathrm{Hg}$ accumulation (Korbas et al., 2013). Pereira et al. (2014) confirmed different affinities of $\mathrm{Hg}$ for lens and the remaining eye tissues in wild fish. Even without consensus, the previous discussion has been focused on $\mathrm{Hg}$ only, whereas for other elements there is no knowledge on how they can reach the fish eyes.

The levels of trace elements in the blood, gills, liver and kidney of $L$. aurata from the Tagus estuary can allow discussion on the main route of metals(loids) to the eyes, namely directly from the water and/or indirectly via systemic distribution [comprising either waterborne metals 
(loids) uptake by the gills and dietary uptake]. Two different patterns were found for the analysed elements in the blood, namely one for $\mathrm{Zn}$, $\mathrm{Cu}$, As, $\mathrm{Cd}$ and $\mathrm{Hg}$, whose levels did not differ significantly between BAR and VF, suggesting that these elements are not circulating in fish body and were probably retained in the eyes upon direct uptake from the water. A second pattern comprised only $\mathrm{Pb}$, for which levels were one order of magnitude higher in the blood of fish from BAR than VF, pointing out that $\mathrm{Pb}$ is being distributed through the bloodstream possibly reaching other organs besides the eyes. In fact, significantly higher levels of $\mathrm{Pb}$ were also found in the gills, liver and kidney of BAR fish. Based on these two patterns, it can be speculated that $L$. aurata eyes incorporated most trace elements directly from the water, while both direct and indirect uptake pathways (either from water via gills or from food) may have contributed for $\mathrm{Pb}$ accumulation in fish eyes. Similarly to $\mathrm{Pb}$, significantly higher levels of $\mathrm{Cd}$ were recorded in the gills and liver of BAR fish. However, no significant increases were found in the blood, suggesting that Cd was not being substantially distributed in the fish body, as at last corroborated by the absence of spatial differences for accumulated levels in the kidney. Since the current study comprised only a sampling time, further investigations are needed to confirm the two different patterns described for metals organotropism in L. aurata at the Tagus estuary.

The subcellular ligand(s) to which metal ions bind in the fish eyes remain unknown, while in human models it has been suggested that melanosomes have a high affinity for trace elements (Erie et al., 2005). The BRB (blood-retinal barrier) and BBB (blood-brain barrier) basically share the same barrier system, and therefore it is assumed that compounds that can permeate the BBB can also permeate the BRB. Absorption depends upon passive diffusion characteristics, transporters at the $\mathrm{BBB} / \mathrm{BRB}$, metabolism, and differences between the relative substance binding affinity of plasma proteins and retinal/brain tissues (Watanabe et al., 2012). The BBB and the BRB greatly limit diffusion of non-lipophilic substances into and out of the retina/brain (Pardridge, 2003). The penetration of hydrophilic solutes via the intercellular cleft is severely restricted by the tight junction barrier, thus only lipophilic compounds with low molecular weight can passively diffuse into the brain and retina by a trans-cellular route (Hitchcock and Pennington, 2006). Free metal ions and complexes of the metal with an amino acid or protein (such as transferrin) are quite hydrophilic, therefore they would not be expected to distribute across the BRB and the BBB at a rate that is sufficient to meet the requirements of the brain. Leucine system (e.g. large neutral amino acid system, LAT1) mediates the bidirectional transport of leucine and phenylalanine across the $\mathrm{BBB} / \mathrm{BRB}$ to provide the brain/retina the amino acids required and remove excess amino acids and similar substances when they accumulate as metabolic products. Therefore, it is anticipated that metal distribution across the BRB/BBB might be transporter mediated (Yokel et al., 2006), which could explain the accumulation of $\mathrm{Pb}$ in $L$. aurata eyes upon redistribution after water and food intake.

In the light of previous assertions on the similarity of transport processes across $\mathrm{BBB}$ and $\mathrm{BRB}$, a higher accumulation of $\mathrm{Pb}$ at brain of BAR fish would be expected. However, contrastingly to the eyes, the brain of $L$. aurata at BAR did not accumulate significantly higher levels of $\mathrm{Pb}$, even if enhanced concentrations were detected in the blood. It can be hypothesized that the brain of $L$. aurata is relatively well protected against $\mathrm{Pb}$ neurotoxicity under these very specific environmental conditions, while the eyes are more vulnerable to $\mathrm{Pb}$ exposure. This is an interesting result considering the widely described neurotoxic effects of $\mathrm{Pb}$ in mammals (Toscano and Guilarte, 2005; Verina et al., 2007; Verstraeten et al., 2008) and of the brain vulnerability in wild L. aurata to other trace elements (particularly to Hg) (Mieiro et al., 2011; Pereira et al., 2014). Indeed, Katti and Sathyanesan (1986) demonstrated that long-term exposure to $\mathrm{Pb}$ causes neurochemical alterations in the brain of the catfish Clarias batrachus by increasing histamine and serotonin levels, while decreasing gamma aminobutyric acid levels and monoamine oxidase and acetylcholinesterase activities. However, in that study fish were exposed to levels $(5 \mathrm{mg} / \mathrm{L})$ much higher than those found at the BAR area of the Tagus estuary $(0.81 \mu \mathrm{g} / \mathrm{L})$. The same occurred in Tulasi et al. (1992) where fish were exposed to levels that ranged from 1.25 to $20 \mathrm{mg} / \mathrm{L}$ causing a significant accumulation of $\mathrm{Pb}$ in the brain. At BAR area, $\mathrm{Pb}$ levels in the water were more than 1000 times lower than those used in the previous studies probably explaining that discrepancy. It is worth to highlight that the glass eel exposure to waterborne $\mathrm{Pb}(50 \mu \mathrm{g} / \mathrm{L})$ during 2 consecutive weeks was not followed by the significant accumulation of $\mathrm{Pb}$ in any of the brain areas, as deeply examined by microanalyses (Godinho et al., 2015). These data suggested that $\mathrm{Pb}$ was unable to cross the $\mathrm{BBB}$ going into the same direction as the current results on wild $L$. aurata. Lead complexes with inorganic and organic ligands in natural waters (Baatrup, 1991). Within the $\mathrm{pH}$ range of most waters, $\mathrm{Pb}$ precipitates as $\mathrm{Pb}(\mathrm{OH})^{+}$and $\mathrm{PbHCO}_{3}{ }^{+}$ with increasing concentration of soluble $\mathrm{Pb}$ at lower $\mathrm{pH}$ (Baatrup, 1991). Therefore, the accumulation of $\mathrm{Pb}$ in fish is expected to be smaller when compared to $\mathrm{Hg}$ and $\mathrm{Cu}$, partly because the low solubility of $\mathrm{Pb}$ salts restricts movements across cell membranes. Accordingly, it was speculated that $\mathrm{Pb}$ did not represent a threat to fish (Baatrup, 1991). However, this hypothesis was viewed with much caution at the time, because of the limited studies on $\mathrm{Pb}$ toxicity in fish and also due to its recognized toxicity (including neurotoxicity) in mammals. Since a significant accumulation of $\mathrm{Pb}$ was found in mullets eyes at BAR, it occurs probably in the water at BAR as available forms for uptake, although $\mathrm{Pb}$ speciation was not considered in this work. More studies are still needed to better understand the environmental conditions that promote a significant accumulation of $\mathrm{Pb}$ in fish brain, as well as the anatomo-physiological features that prevent it.

4.2. Neurosensorial toxicity in wild L. aurata assessed as pro-oxidant status and association with metals(loids) accumulation

The high levels of metals(loids) found in the eyes of fish from BAR could be on the basis of the observed toxic effects, namely those related with oxidative stress. The enhancement of reactive oxygen species (ROS) is a critical event in the neurotoxicity of metals (Farina et al., 2011), associated with the high affinity of some trace elements to thiol groups of proteins and non-protein molecules, namely glutathione (GSH). In fact, an increase of SOD and GPx activities were recorded in the eyes of fish from BAR, as well as an increase of total GSH content, indicating pro-oxidant conditions probably related with the higher accumulation of trace elements at BAR. Levels of $\mathrm{Pb}$ in the eyes of BAR fish exceeded 10 times those recorded in specimens from VF, suggesting this metal as the most probable cause for the recorded change on the antioxidant protection. Moreover, the levels of $\mathrm{Pb}$ in mullet eyes at BAR were 1000 times higher than those recorded in human retina with agerelated macular degeneration associated with irreversible vision loss (Erie et al., 2009), corroborating the potential of $\mathrm{Pb}$ as a damaging agent to mullets' eyes. The mechanisms underlying $\mathrm{Pb}$ neurotoxicity are still a matter of research. So far, some potential mechanisms for $\mathrm{Pb}$ toxicity include the capacity of this element to affect cell membrane biophysics, cause oxidative stress and trigger oxidant-sensitive transcription factors (e.g. Marchetti, 2003; Toscano and Guilarte, 2005). Studies on a rat retinal model indicated that low levels of exposure to $\mathrm{Pb}$ produce scotopic visual deterioration (Fox et al., 1997). While $\mathrm{Pb}$ toxicity has been linked to visual dysfunction in mammals, no studies have been performed to evaluate $\mathrm{Pb}$ effects on fish vision. Nevertheless, it is plausible that $\mathrm{Pb}$ accumulation in $L$. aurata eyes at BAR, as well as of other neurotoxic metals, could be on the basis of functional injury as perceived by changes on the antioxidant protection status.

In accordance with current findings in $L$. aurata eyes, it was found that SOD affords protection against the superoxide anion in the rabbit eye (Bhuyan and Bhuyan, 1986), as it catalyses the dismutation of the superoxide radical into hydrogen peroxide $\left(\mathrm{H}_{2} \mathrm{O}_{2}\right)$ and molecular oxygen $\left(\mathrm{O}_{2}\right)$, thus reducing the intracellular levels of that potent ROS. Moreover, GPx is widely known for catalyzing the hydrogen peroxide 
into water with the concomitant conversion of reduced glutathione (GSH) to its oxidized form (glutathione disulphide - GSSG). GPx also serves as an active scavenger of free radicals, making it an essential protective molecule against potential cell injury and neuropathological conditions (Hussain et al., 1999). Enhanced activities of GPx in $L$. aurata eyes are in accordance with previous findings in the eyes of the same species from a $\mathrm{Hg}$ contaminated lagoon (Aveiro lagoon), while SOD activity was depleted (Pereira et al., 2016). Discrepancies between the current study and the previous one can be related with the toxicant specific mechanisms. At $\mathrm{BAR}, \mathrm{Pb}$ was identified as the most probable toxicant agent, whereas a primordial contamination by $\mathrm{Hg}$ occurs at Aveiro lagoon. Also, tGSH signalised a pro-oxidant challenge in the eyes of fish from the most contaminated area of the Tagus estuary, which is in agreement with the higher accumulation of trace elements, particularly Pb. GSH acts as a chelating agent for metals, inhibiting their toxic effects and assisting with their excretion from the cells (Ciriolo et al., 1990). There is an unusually high concentration of the reducing compound glutathione (GSH) in human lens, where it functions as an essential antioxidant, vital for maintenance of the tissue's transparency. In conjunction with an active glutathione redox cycle located in the lens epithelium and surficial cortex, GSH detoxifies potentially damaging oxidants such as $\mathrm{H}_{2} \mathrm{O}_{2}$ and dehydroascorbic acid. An identical spatial variation was found for tGSH in the eyes of fish from Aveiro lagoon (Pereira et al., 2016) exposed to $\mathrm{Hg}$, encouraging the further investigation of $\mathrm{tGSH}$ and GPx as sensitive endpoints to the presence of trace elements in the ocular tissues.

There is a body of evidence that points towards the possibility of fish eyes could be under pro-oxidant conditions at a contaminated area of the Tagus estuary, related with the enhanced accumulation of metals (particularly of $\mathrm{Pb}$ ). Differently, no changes on antioxidants' levels were recorded in the brain (except CAT), which is in accordance with the absence of a significant accumulation of metals(loids). Consistently, no differences were found for the cell density in 4 areas of the brain of fish, namely the lateral pallium, hypothalamus, optic tectum and cerebellum. Whilst the high contamination detected at BAR area in the Tagus estuary, no neurotoxicity manifestations were found in $L$. aurata from this estuary, in line with the absence of significant accumulation of metals(loids).

\section{Conclusions}

According to the present results, it can be concluded that:

- The eyes of L. aurata are highly vulnerable to metals(loids) contamination, as noticed by the enhanced accumulation, probably related with waterborne direct uptake. Differently, direct water uptake and indirect pathways may have contributed to $\mathrm{Pb}$ accumulation in the eyes.

- $\mathrm{Pb}$ was distributed by bloodstream along $L$. aurata body, reaching the liver and kidney upon uptake.

- Metals(loids) accumulation in the eyes of fish from the most contaminated site (BAR) was at the basis of a pro-oxidant condition in ocular cells.

- No neurotoxicity was found in L. aurata from Tagus estuary, as assessed by oxidative stress profiles and brain morphology (viz. cell density).

- L. aurata eyes reflected better metal(loids) contamination than the brain, even if both organs are physiologically well protected by biological barriers, pointing out that the higher vulnerability of the eyes is related with their direct contact with the external medium.

\section{Acknowledgements}

Thanks are due for the financial support to CESAM (UID/AMB/ 50017 - POCI-01-0145-FEDER-007638), to FCT/MCTES through national funds (PIDDAC), and the co-funding by the FEDER, within the
PT2020 Partnership Agreement and Compete 2020, and due for the Research Project NEUTOXMER project (FCT-PTDC/AAGREC/2488/ 2012) (which provided a research grant to Sónia Puga). Authors also acknowledge the post-doctoral grants SFRH/BPD/69563/2010 and SFRH/BPD/107718/2015 (Patrícia Pereira), SFRH/BPD/91498/2012 (Joana Raimundo) and SFRH/BPD/88947/2012 (Sofia Guilherme).

\section{Appendix A. Supplementary data}

Supplementary data related to this article can be found at https:// doi.org/10.1016/j.marenvres.2018.07.001.

\section{References}

Badsha, K.S., Goldspink, C.R., 1982. Preliminary observations on the heavy metal content of four species of freshwater fish in N.W. England. J. Fish. Biol. 21, 251-267.

Baker, M., Cerniglia, G., Zaman, A., 1990. Microtiter plate assay for the measurement of glutathione and glutathione disulfide in large numbers of biological samples. Anal. Biochem. 190, 360-365.

Baatrup, E., 1991. Structural and functional effects of heavy metals on the nervous system, including sense organs, of fish. Comp. Biochem. Physiol. 100, 253-257.

Beauvais, S.L., Jones, S.B., Parris, J.T., Brewer, S.K., Little, E.E., 2001. Cholinergic and behavioral neurotoxicity of carbaryl and cadmium to larval rainbow trout (Oncorhynchus mykiss). Ecotoxicol. Environ. Saf. 49 (1), 84-90.

Berntssen, M.H.G., Aatland, A., Handy, R.D., 2003. Chronic dietary mercury exposure causes oxidative stress, brain lesions, and altered behaviour in Atlantic salmon (Salmo salar) parr. Aquat. Toxicol. 65 (1), 55-72.

Bhuyan, K.C., Bhuyan, D.K., 1986. Lipid peroxidation in cataract of the human. Life Sci. $38,1463-1471$.

Canário, J., Vale, C., Caetano, M., 2005. Distribution of monomethylmercury and mercury in surface sediments of the Tagus Estuary (Portugal). Mar. Pollut. Bull. 50, 1142-1145.

Cardoso, O., Puga, S., Brandão, F., Canário, J., O'Driscoll, N.J., Santos, M.A., Pacheco, M., Pereira, P., 2017. Oxidative stress profiles in brain point out a higher susceptibility of fish to waterborne divalent mercury compared to dietary organic mercury. Mar. Pollut. Bull. 122 (1-2), 110-121.

Cesário, R., Hintelmann, H., O'Driscoll, N.J., Monteiro, C.E., Caetano, M., Nogueira, M., Mota, A.M., Canário, J., 2017. Mercury and methylmercury dynamics in two high contaminated areas of Tagus estuary (Portugal). Water Air Soil Pollut. 228, 257-275.

Ciriolo, M.R., Desideri, A., Paci, M., Rotilio, G., 1990. Reconstitution of Cu,Zn-superoxide dismutase by the $\mathrm{Cu}(\mathrm{I})$.glutathione complex. J. Biol. Chem. 265 (19), 11030-11034.

Claiborne, A., 1985. Catalase activity. In: Greenwald, R.A. (Ed.), CRC Handbook of Methods in Oxygen Radical Research. CRC Press, Boca Raton, FL, pp. 283-284.

Cribb, A., Leeder, J., Spielberg, S., 1989. Use of a microplate reader in an assay of glutathione reductase using 5,5'-dithiobis(2-nitrobenzoic acid). Anal. Biochem. 183, 195-196.

Costley, C.T., Mossop, K.F., Dean, J.R., Garden, L.M., Marshall, J., Carroll, J., 2000. Determination of mercury in environmental and biological samples using pyrolysis atomic absorption spectrometry with gold amalgamation. Anal. Chim. Acta 405, 179-183.

Duarte, B., Reboreda, R., Caçador, I., 2008. Seasonal variation of extracellular enzymatic activity (EEA) and its influence on metal speciation in a polluted salt marsh. Chemosphere 73, 1056-1063.

Erie, J.C., Butz, J.A., Good, J.A., Erie, E.A., Burrit, M.F., Cameron, D., 2005. Heavy metal concentrations in human eyes. Am. J. Ophthalmol. 139 (5), 888-893.

Erie, J.C., Good, J.A., Butz, J.A., Pulido, J.S., 2009. Reduced zinc and copper in the retinal pigment epithelium and choroid in age-related macular degeneration. Am. J. Ophthalmol. 147, 276-282.

Falluel-Morel, A., Sokolowski, K., Sisti, H.M., Zhou, X., Shors, T.J., DiCicco-Bloom, E., 2007. Developmental mercury exposure elicits acute hippocampal cell death, reductions in neurogenesis, and severe learning deficits during puberty. J. Neurochem. 103, 1968-1981.

Farina, M., Aschner, M., Rocha, J.B., 2011. Oxidative stress in MeHg-induced neurotoxicity. Toxicol. Appl. Pharmacol. 256 (3), 405-417.

Farina, M., Avila, D.S., Rocha, J.B., Aschner, M., 2013. Metals, oxidative stress and neurodegeneration: a focus on iron, manganese and mercury. Neurochem. Int. 62, 575-594.

França, S., Vinagre, C., Caçador, I., Cabral, H.N., 2005. Heavy metal concentrations in sediment, benthic invertebrates and fish in three salt marsh areas subjected to different pollution loads in the Tagus Estuary (Portugal). Mar. Pollut. Bull. 50, 998-1003.

Fox, D.A., Campbell, M.L., Blocker, Y.S., 1997. Functional alter- ations and apoptotic cell death in the retina following developmental or adult lead exposure. Neurotoxicology $18,645-664$.

Giri, M., Iqbal, M., Athar, 1996. Porphyrine-mediated photosensitization has a weak tumor promoting e ect in mouse skin: possible role of in situ generated reactive oxygen species. Carcinogenesis 17, 2023-2028.

Gornall, A., Bardawill, C., David, M., 1949. Determination of serum proteins by means of the biuret reaction. J. Biol. Chem. 177, 751-766.

Graves, S.D., Kidd, K.A., Houlahan, J.E., Munkittrick, K.R., 2017. General and histological indicators of health in wild fishes from a biological mercury hotspot in northeastern 
North America. Environ. Toxicol. Chem. 36, 976-987.

Godinho, R., Pereira, P., Raimundo, J., Pinheiro, T., Pacheco, M., 2015. Micro-scale elemental mapping of brain structures in glass eel Anguilla anguilla exposed to Lead. In: SETAC Europe 25th Annual Meeting in Barcelona, Spain, May 2015, (poster).

Guilherme, S., Gaivao, I., Santos, M.A., Pacheco, M., 2009. Tissue specific DNA damage in the European eel (Anguilla anguilla) following a short-term exposure to a glyphosatebased herbicide. Toxicol. Lett. 189 (1), 212.

Guilherme, S., Gaivão, I., Santos, M.A., Pacheco, M., 2012. DNA damage in fish (Anguilla anguilla) exposed to a glyphosate-based herbicide - elucidation of organ-specificity and the role of oxidative stress. Mutat. Res. Genet. Toxicol. Environ. Mutagen $743,1-9$.

Gundersen, H., Jensen, E., 1987. The efficiency of systematic sampling in stereology and its prediction. J. Microsc. 147, 229-263.

Gundersen, H., Bendtsen, T.F., Korbo, L., Marcussen, N., Møller, A., Nielsen, K., Nyengaard, J., Pakkenberg, B., Sørensen, F.B., Vesterby, A., 1988. Some new, simple and efficient stereological methods and their use in pathological research and diagnosis. APMIS 96, 379-394.

Habig, W., Pabst, M., Jokoby, W., 1974. Glutathione-S-transferase: the first enzymatic step in mercapturic acid formation. J. Biol. Chem. 249, 7130-7139.

Hitchcock, S.A., Pennington, L.D., 2006. Structure-Brain exposure relationships chemistry. J. Med. Chem. 49 (26), 7559-7583.

Höistad, M., Heinsen, H., Wicinski, B., Schmitz, C., Hof, P.R., 2013. Stereological assessment of the dorsal anterior cingulate cortex in schizophrenia: absence of changes in neuronal and glial densities. Neuropathol. Appl. Neurobiol. 39, 348-361.

Hussain, S., Atkinson, A., Thompson, S., Khan, A., 1999. Accumulation of mercury and its effect on antioxidant enzymes in brain, liver, and kidneys of mice. J. Environ. Sci. Health 34, 645-660.

IPIMAR, 2004. Programa de Monitorização do Estuário do Tejo e Ribeiras (Sedimento Superficial). Relatório. Relatório Semestral, Campanha de Julho 2004. Dezembro 2004. pp. 36.

Katti, S.R., Sathyanesan, A.G., 1986. Lead nitrate induced changes in brain constituents of the freshwater fish, Clarias bathrachus (L.). Neurotoxicology 7, 47-52.

Kim, J.H., Oh, C.W., Kang, J.C., 2017. Antioxidant responses, neurotoxicity, and metallothionein gene expression in juvenile Korean rockfish Sebastes schlegelii under dietary lead exposure. J. Aquat. Anim. Health 29 (2), 112-119.

Korbas, M., Blechinger, S.R., Krone, P.H., Pickering, I.J., George, G.N., 2008. Localizing organomercury uptake and accumulation in zebrafish larvae at the tissue and cellular level. Proc. Natl. Acad. Sci. U.S.A. 105, 12108-12112.

Korbas, M., MacDonald, T.C., Pickering, I.J., George, G.N., 2012. Chemical form matters: differential accumulation of mercury following inorganic and organic mercury exposures in zebrafish larvae. ACS Chem. Biol. 7, 411-420.

Korbas, M., Lai, B., Vogt, S., Gleber, S.C., Karunakaran, C., Pickering, I.J., George, G.N., 2013. Methylmercury targets photoreceptor outer segments. ACS Chem. Biol. 8 (10), 2256-2263.

Larsen, J.O., Brændgaard, H., 1995. Structural preservation of cerebellar granule cells following neurointoxication with methyl mercury: a stereological study of the rat cerebellum. Acta Neuropathol. 90, 251-256.

Levesque, H., Dorval, J., Van Der Kraak, G.J., Campbell, P.G.C., Hontela, A., 2003. Hormonal, morphological and physiological responses of yellow perch (Perca flavescens) to chronic environmental metal exposures. J. Toxicol. Environ. Health 66, $657-676$.

Liu, B., Nie, Y., Hu, K., Yang, J., 2017. The diagenetic geochemistry and contamination assessment of iron, cadmium, and lead in the sediments from the Shuangtaizi estuary, China. Environ. Health Sci. 76, 168-179.

Marchetti, C., 2003. Molecular targets of lead in brain neurotoxicity. Neurotox. Res. 5, 221-236.

Marques, A., Pilo, D., Araujo, O., Pereira, F., Guilherme, S., Carvalho, S., Santos, M.A., Pacheco, M., Pereira, P., 2016. Propensity to metal accumulation and oxidative stress responses of two benthic species (Cerastoderma edule and Nephtys hombergii): are tolerance processes limiting their responsiveness? Ecotoxicology 25 (4), 664-676.

Marques, A., Pilo, D., Carvalho, S., Araújo, O., Guilherme, S., Santos, M.A., Vale, C., Pereira, F., Pacheco, M., Pereira, P., in press. Metal bioaccumulation and oxidative stress profiles in Ruditapes philippinarum - insights towards its suitability as bioindicator of estuarine metal contamination. Ecol. Indicat.

Mieiro, C.L., Pacheco, M., Pereira, M.E., Duarte, A.C., 2009. Mercury distribution in key tissues of fish (Liza aurata) inhabiting a contaminated estuary - implications for human and ecosystem health risk assessment. J. Environ. Monit. 11, 1004-1012.

Mieiro, C.L., Ahmad, I., Pereira, M.E., Duarte, C., Pacheco, M., 2010. Antioxidant system breakdown in brain of feral golden grey mullet (Liza aurata) as an effect of mercury exposure. Ecotoxicology 19 (6), 1034-1045.

Mieiro, C.L., Pereira, M.E., Duarte, A.C., Pacheco, M., 2011. Brain as a critical target of mercury in environmentally exposed fish (Dicentrarchus labrax) - bioaccumulation and oxidative stress profiles. Aquat. Toxicol. 103, 233-240.

Mohandas, J., Marshall, J., Duggin, G., Horvath, J., 1984. Differential distribution of glutathione and glutathione-related enzymes in rabbit kidney: possible implications in analgesic nephropathy. Biochem. Pharmacol. 33, 1801-1807.

Mulvey, M., Diamon, S.A., 1991. Genetic factors and tolerance acquisition in populations exposed to metals and metalloids. In: Newman, M.C. (Ed.), Metal Ecotoxicology: Concepts and Applications. Lewis Publishers, Chelsea MI, pp. 301-321.

Neto, A.F., Costa, J.L., Costa, M.J., Pereira, M.E., Duarte, A., Caçador, I., Domingos, I., 2011. Accumulation of metals in Anguilla anguilla from the Tagus estuary and relationship to environmental contamination. J. Appl. Ichthyol. 27, 1265-1271.

Obiorah, M., McCandlish, E., Buckley, B., DiCicco-Bloom, E., 2015. Hippocampal developmental vulnerability to methylmercury extends into prepubescence. Front.
Neurosci. 9, 150

Pardridge, W.M., 2003. Blood-brain barrier drug targeting: the future of brain drug development. Mol. Interv. 51 (2), 90-105.

Pereira, P., de Pablo, H., Vale, C., Pacheco, M., 2010. Combined use of environmental data and biomarkers in fish (Liza aurata) inhabiting a eutrophic and metal-contaminated coastal system - gills reflect environmental contamination. Mar. Environ. Res. 69 (2), 53-62.

Pereira, P., Raimundo, J., Araujo, O., Canario, J., Almeida, A., Pacheco, M., 2014. Fish eyes and brain as primary targets for mercury accumulation - a new insight on environmental risk assessment. Sci. Total Environ. 494, 290-298.

Pereira, P., Raimundo, J., Barata, M., Araujo, O., Pousao-Ferreira, P., Canario, J., Almeida, A., Pacheco, M., 2015. A new page on the road book of inorganic mercury in fish body - tissue distribution and elimination following waterborne exposure and post-exposure periods. Metall 7 (3), 525-535.

Pereira, P., Puga, S., Cardoso, V., Pinto-Ribeiro, F., Raimundo, J., Barata, M., PousãoFerreira, P., Pacheco, M., Almeida, A., 2016. Inorganic mercury accumulation in brain following waterborne exposure elicits a deficit on the number of brain cells and impairs swimming behavior in fish (white seabream—Diplodus sargus). Aquat. Toxicol. 170, 400-412.

Pierron, F., Bourret, V., St-Cyr, J., Campbell, P.G.C., Bernatchez, L., Couture, P., 2009. Transcriptional responses to environmental metal exposure in wild yellow perch (Perca flavescens) collected in lakes with differing environmental metal concentrations (Cd, Cu, Ni). Ecotoxicology 18, 620-631.

Piló, D., Carvalho, S., Pereira, P., Gaspar, M.B., Leitão, A., 2017. Is metal contamination responsible for increasing aneuploidy levels in the Manila clam Ruditapes philippinarum? Sci. Total Environ. 577, 340-348.

Puga, S., Pereira, P., Pinto-Ribeiro, F., O'Driscoll, N.J., Mann, E., Barata, M., PousãoFerreira, P., Canário, J., Almeida, A., Pacheco, M., 2016. Unveiling the neurotoxicity of methylmercury in fish (Diplodus sargus) through a regional morphometric analysis of brain and swimming behavior assessment. Aquat. Toxicol. 180, 320-333.

Puga, S., Cardoso, V., Pinto-Ribeiro, F., Pacheco, M., Almeida, A., Pereira, P., 2018. Brain morphometric profiles and their seasonal modulation in fish (Liza aurata) inhabiting a mercury contaminated estuary. Environ. Pollut. 237, 318-328.

Richards, K.L., Kurniawan, N.D., Yang, Z., Kim, T.H., Keller, M.D., Low, J., Ullmann, J.F., Cole, S., Foong, S., Galloway, G.J., 2013. Hippocampal volume and cell density changes in a mouse model of human genetic epilepsy. Neurology 80, 1240-1246.

Shanker, G., Aschner, M., 2003. Methylmercury-induced reactive oxygen species formation in neonatal cerebral astrocytic cultures is attenuated by antioxidants. Mol. Brain Res. 110 (1), 85-91.

Sokolowski, K., Obiorah, M., Robinson, K., McCandlish, E., Buckley, B., DiCicco-Bloom, E., 2013. Neural stem cell apoptosis after low-methylmercury exposures in postnatal hippocampus produce persistent cell loss and adolescent memory deficits. Dev. Neurobiol. 73, 936-949.

Sørensen, F.W., Larsen, J.O., Eide, R., Schiønning, J.D., 2000. Neuron loss in cerebellar cortex of rats exposed to mercury vapor: a stereological study. Acta Neuropathol. 100, 95-100.

Takatsu, A., Kuroiwa, T., Uchiumi, A., 1999. Arsenic accumulation in organs of the fresh water fish Tribolodon hakanensis. J. Trace Elem. Med. Biol. 13, 176-179.

Tietze, F., 1969. Enzymatic method for quantitative determination of nanogram amounts of total and oxidized glutathione. Anal. Biochem. 27, 502-522.

Toscano, C.D., Guilarte, R.G., 2005. Lead neurotoxicity: from exposure to molecular effects. Brain Res. Rev. 49, 529-554.

Tulasi, S.J., Reddy, P.U.M., Ramana Ra, J.V., 1992. Accumulation of lead and effects on total lipids and lipid derivatives in the freshwater fish Anabas testudineus (Bloch). Ecotoxicol. Environ. Saf. 23, 33-38.

Vale, C., Canário, J., Caetano, M., Lavrado, J., Brito, P., 2008. Estimation of the anthropogenic fraction of elements in surface sediments of the Tagus Estuary (Portugal). Mar. Pollut. Bull. 56, 1364-1367.

Verina, T., Rohde, C.A., Guilarte, T.R., 2007. Environmental lead exposure during early life alters granule cell neurogenesis and morphology in the hippocampus of young adult rats. Neuroscience 145, 1037-1047.

Verstraeten, S.V., Aimo, L., Oteiza, P.I., 2008. Aluminium and lead: molecular mechanisms of brain toxicity. Arch. Toxicol. 82, 789-802.

Watanabe, K., Nishimura, Y., Nomoto, T., Umemoto, N., Zhang, Z., Zhang, B., Kuroyanagi, J., Shimada, Y., Shintou, T., Okano, M., Miyazaki, T., Imamura, T., Tanaka, T., 2012. In vivo assessment of the permeability of the blood-brain barrier and blood-retinal barrier to fluorescent indoline derivatives in zebrafish. BMC Neurosci. 13, 101.

Webster, T.M.U., Bury, N., van Aerle, R., Santos, E.M., 2013. Global transcriptome profiling reveals molecular mechanisms of metal tolerance in a chronically exposed wild population of Brown trout. Environ. Sci. Technol. 47, 8869-8877.

West, M., Slomianka, L., Gundersen, H.J.G., 1991. Unbiased stereological estimation of the total number of neurons in the subdivisions of the rat hippocampus using the optical fractionator. Anat. Rec. 231, 482-497.

West, S.G., Finch, J.F., Curran, P.J., 1995. Structural equation models with nonnormal variables. In: Hoyle, R.H. (Ed.), Structural Equation Modeling: Concepts, Issues, and Applications. SAGE Publications, London, pp. 56-75.

Yokel, R.A., Lasley, S.M., Dorman, D.C., 2006. The speciation of metals in mammals influences their toxicokinetics and toxicodynamics and therefore human health risk assessment. J. Toxicol. Environ. Health B 9, 63-85.

Zhang, H., Davison, W., 1999. Diffusional characteristics of hydrogels used in DGT and DET techniques. Anal. Chim. Acta 398, 329-340.

Zwolsman, J.J., van Eck, G.T.M., Burger, G., 1996. Spatial and temporal distribution of trace metals in sediments from the Scheldt Estuary, South-west Netherlands. Estuar. Coast Shelf Sci. 43, 55-79. 